\title{
SZYMON OPANIA
}

Katedra Urbanistyki i Planowania Przestrzennego

Wydział Architektury

Politechnika Śląska

\section{STUDIUM STRUKTURY PRZESTRZENNEJ MALEGO MIASTA \\ A STUDY OF THE SPATIAL STRUCTURE OF A SMALL TOWN}

Artykuł wpłynął do redakcji 10.01.2016; po recenzjach zaakceptowany 20.10.2016.

Opania S., 2016, Studium struktury przestrzennej małego miasta, [w:] Bartosiewicz B. (red.), Tendencje w rozwoju gospodarczym i przestrzennym matych miast $w$ Polsce. Trends in economical and spatial development of small towns in Poland, ,Space - Society - Economy”, 17, Institute of the Built Environment and Spatial Policy, Wydawnictwo Uniwersytetu Łódzkiego, Łódź, s. 49-66.

Dr hab. inż. arch. Szymon Opania, Katedra Urbanistyki i Planowania Przestrzennego, Wydziat Architektury, Politechnika Ślaska, ul. Akademicka 7, 44-100 Gliwice; e-mail: szymon.opania@polsl.pl

\section{Zarys treści}

W województwie śląskim zlokalizowanych jest 35 miast kwalifikujących się do grupy miast małych, z czego najmniejsze - Sośnicowice liczą poniżej 2 tys. mieszkańców, zaś Orzesze z liczbą 19199 mieszkańców jest największym małym miastem w grupie. Pojawia się więc pytanie, czy wielkość miasta ma wpływ na jego miejskość? I czy największe z nich - Orzesze jest „,bardziej miejskie" od pozostałych mniejszych miast?

Celem artykułu jest próba wykazania przydatności diagnozy struktury przestrzennej miasta, jako narzędzia z dziedziny planowania przestrzennego i urbanistyki, pozwalającego dać odpowiedź na postawiony problem, jak i wskazać ewentualne działania zmierzające do podniesienia jakości życia W mieście.

\section{Słowa kluczowe}

Struktura przestrzenna, analiza problemów, planowanie przestrzenne. 


\subsection{WPROWADZENIE}

W pojęciu „małe miasto" ukrytych jest wiele znaczeń, które wydają się być istotne z punktu widzenia analizy ich struktur przestrzennych.

Zawarte w tytule pojęcie „małe” odwołuje się do kryterium liczby mieszkańców, które stanowi podstawę przynależności miasta do określonej grupy wielkościowej. Granice poszczególnych grup pozwalają na podział miast na kategorie wielkościowe. Natomiast drugie pojęcie „miasto”, które w podstawowym znaczeniu może być rozpatrywane jako historycznie ukształtowana jednostka osadnicza z konkretną społecznością, skoncentrowana na pewnym obszarze o specyficznej fizjonomii, rozumiane jest zgodnie $\mathrm{z}$ podstawowym znaczeniem dla dziedziny architektury i urbanistyki jako odrębny typ krajobrazu (Chmielewski 2001). To drugie znaczenie w konsekwencji sprzyjać może większej ilości i różnorodności kontaktów między ludźmi (Gehl 2014). Dwa komponenty miasta: fizjonomiczny, w skład którego wchodzi zabudowa, przestrzenie publiczne, infrastruktura techniczna i kompozycja urbanistyczna wraz z aktywną społecznością, składają się na przestrzeń miasta i toczące się w nim życie, są esencją miejskości.

Pojawia się zatem pytanie - czy wielkość miasta ma wpływ na jakość życia w mieście? I czy w największym z nich - Orzeszu, warunki życia są lepsze niż w innych, mniejszych miastach?

Celem artykułu jest próba wykazania przydatności studium struktury przestrzennej miasta, jako narzędzia z dziedziny planowania przestrzennego i urbanistyki, pozwalającego dać odpowiedź na postawiony problem, jak i wskazać ewentualne działania naprawcze zmierzające do podniesienia jakości życia w mieście.

Istotę problemu podkreśla Strategia Rozwoju Województwa Śląskiego „ŚLĄSKIE 2020+" określając cel operacyjny B.3, jako harmonię społeczną i wysoki kapitał zaufania oraz dogodne warunki życia mieszkańców, który powinien być realizowany poprzez: wyposażanie przestrzeni publicznych w infrastrukturę umożliwiającą wspólne spędzanie czasu przez mieszkańców oraz integrację społeczności lokalnych (Strategia... 2013).

\subsection{MAŁE MIASTA WOJEWÓDZTWA ŚLĄSKIEGO - KRÓTKI PRZEGLĄD}

Pojęcie „małe miasto” dotyczy w województwie śląskim 35 miast kwalifikujących się do grupy miast małych ${ }^{1}$, z czego najmniejsze z nich - Sośnicowice

${ }^{1} \mathrm{~W}$ literaturze naukowej można spotkać wiele kryteriów, na podstawie których wyznacza się małe miasta. W niektórych opracowaniach do małych miast zalicza te jednostki, których liczba mieszkańców nie przekracza 5 tys. (Chojnicki, Czyż 1989). Inni zaś za małe uznają ośrodki liczące do 10 tys. mieszkańców (Szlachta 1980). Najczęściej przyjmowanym kryterium małych miast jest liczba 20 tys. mieszkańców (Jerczyński 1977; Bagiński 1988; Parysek 2004; Heffner 2005) i to właśnie kryterium przyjęto w artykule. 
i Pilica liczą poniżej 2 tys. mieszkańców, natomiast Orzesze z liczbą $19199^{2}$ mieszkańców jest największym małym miastem w grupie (Strategia... 2012), do której zaliczyć można również Bierun, Pyskowice, Radlin i Radzionków przekraczające liczbę 17 tys. mieszkańców i zbliżające się do granicy 20 tys. mieszkańców. Średnia liczba mieszkańców małych miast województwa śląskiego wynosi 8824 , a zbliżone do tej średniej są miasta: Wojkowice i Poręba (rys. 1).

Problematykę funkcjonalno-przestrzenną małych miast w województwie śląskim poruszali w swoich publikacjach m.in.: K. Heffner i A. Czarnecki (2005), E. Duś (2010), K. Heffner (2008), A. Polko (2010), K. Heffner i T. Marszał (2012), K. Mazur-Belzyt (2016). W odniesieniu do rozważań nad strukturą miejską małych miast województwa śląskiego należy zauważyć, że znaczna ich większość, tj. 23 miasta z $35(66 \%)$ posiadają wyraźnie wykształconą historyczną strukturę przestrzenną. Należą do nich miasta o najmniejszej liczbie mieszkańców, m.in. Sośnicowice, Pilica, Krzanowice, Koziegłowy, Toszek, Strumień. Natomiast w grupie miast największych przeważają miasta o rozproszonej strukturze przestrzennej, m.in. Lędziny, Radzionków, Radlin i Orzesze.

\subsection{ORZESZE - KRÓTKA CHARAKTERYSTYKA}

Orzesze jest miastem leżącym w centralnej części województwa śląskiego, w powiecie mikołowskim. Miejscowość położona jest wzdłuż ważnej drogi krajowej nr 81 łączącej Katowice ze Skoczowem. Ponadto przez Orzesze przebiega droga wojewódzka nr 925: Rybnik-Orzesze-Ruda Śląska-Bytom. Miasto sąsiaduje z gminami Czerwionka-Leszczyny, Łaziska Górne, Mikołów, Ornontowice, Suszec, Wyry, Kobiór i Żory.

Lokalizacja miasta w rozwiniętym gospodarczo regionie oraz bardzo dogodne położenie w stosunku do ośrodków gospodarczych (Mikołów, Łaziska, Żory, Rybnik) i sieci komunikacyjnej o znaczeniu regionalnym i krajowym powoduje, że posiada ono ciekawe oferty inwestycyjne.

W Orzeszu nie działa już żadna kopalnia ani huta, większość złóż wyczerpała się w latach międzywojennych. Obecnie na terenie miasta funkcjonuje duża liczba przedsiębiorstw, wśród nich takie jak: Pol-Am-Pack S.A. oddział Huta Szkła „ORZESZE”, Fabryka Materacy Janpol, Igloland, FVZ.

W 2011 roku na terenie gminy zameldowanych było 19199 osób. W ciągu dekady w Orzeszu nastąpił wzrost mieszkańców o 670 osób. Przyrost ten od 10 lat uwarunkowany jest głównie przez dodatnie saldo migracji, a od 2006 roku także dodatni przyrost naturalny (Lokalny... 2010).

${ }^{2}$ Stan na 31.12.2014 wynosił już 20194 mieszkańców. Dane na podstawie Urzędu Statystycznego w Katowicach, 2015, Ludność, ruch naturalny i migracje w województwie śląskim w 2014 r., Katowice. 


\begin{tabular}{|c|c|c|}
\hline Lp. & Miejscowość & $\begin{array}{l}\text { Liczba } \\
\text { mieszk. }\end{array}$ \\
\hline 1. & Orzesze & 20194 \\
\hline 2. & Bieruń & 19363 \\
\hline 3. & Pyskowice & 18563 \\
\hline 4. & Radlin & 18028 \\
\hline 5. & Radzionków & 17050 \\
\hline 6. & Lędziny & 16749 \\
\hline 7. & Ustroń & 16073 \\
\hline 8. & Skoczów & 14625 \\
\hline 9. & Pszów & 14293 \\
\hline 10. & Kłobuck & 13133 \\
\hline 11. & Wisła & 11198 \\
\hline 12. & Blachownia & 9830 \\
\hline 13. & Wojkowice & 9033 \\
\hline 14. & Poręba & 8749 \\
\hline 15. & Imielin & 8723 \\
\hline 16. & Kalety & 8626 \\
\hline 17. & Miasteczko Śl. & 7383 \\
\hline 18. & Sławków & 7135 \\
\hline 19. & Łazy & 6972 \\
\hline 20. & Koniecpol & 6142 \\
\hline 21. & Szczyrk & 5799 \\
\hline 22. & \begin{tabular}{|l|} 
Siewierz \\
\end{tabular} & 5495 \\
\hline 23. & Kuźnia R. & 5451 \\
\hline 24. & Żarki & 4526 \\
\hline 25. & Krzepice & 4462 \\
\hline 26. & Woźniki & 4422 \\
\hline 27. & Ogrodzieniec & 4349 \\
\hline 28. & Szczekociny & 3726 \\
\hline 29. & Strumień & 3642 \\
\hline 30. & Toszek & 3615 \\
\hline 31. & Wilamowice & 3033 \\
\hline 32. & Koziegłowy & 2449 \\
\hline 33. & Krzanowice & 2209 \\
\hline 34. & Pilica & 1937 \\
\hline 35. & Sośnicowice & 1854 \\
\hline
\end{tabular}

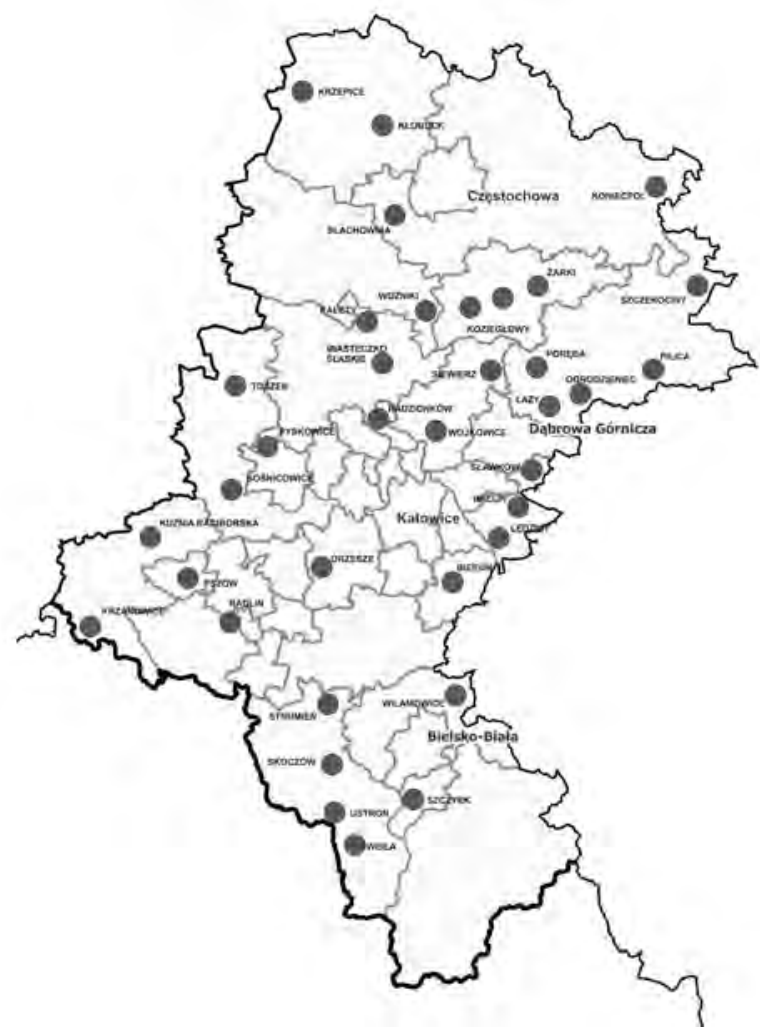

Rys. 1. Ludność i lokalizacja małych miast w województwie śląskim

Źródło: opracowanie własne na podstawie: Urząd Statystyczny w Katowicach, 2015, Ludność, ruch naturalny i migracje $w$ województwie śląskim w 2014 r., Katowice 
Na ogólną powierzchnię 8289 ha użytkowanych gruntów składają się:

- tereny zurbanizowane: 836 ha $(10 \%)$,

- grunty orne: 2356 ha $(28 \%)$,

- lasy i grunty leśne: 4164 ha (50\%),

- łąki i pastwiska: 924 ha (11\%),

- sady: 9 ha (1\%).

Model przestrzenny miasta Orzesze kształtuje się w oparciu o mniejsze jednostki osadnicze, które mają wpływa na podział miasta na dzielnice i sołectwa. Miasto posiada 3 dzielnice administracyjne: Centrum-Orzesze, Jaśkowice, Zawada (tzw. śródmieście, położone na północy gminy) (fot. 1,2) oraz 7 sołectw: Gardawice, Królówka, Mościska, Woszczyce, Zazdrość, Zawiść, Zgoń (Studium... 2010). Taki podział terytorialny ma swoje uwarunkowania kulturowe i historyczne i ma istotny wpływ na poczucie tożsamości przestrzennej mieszkańców. Struktura przestrzenna miasta rozwinęła się głównie w XIX i XX wieku, w czasie transformacji wsi rolniczych $\mathrm{w}$ jednostki będące administracyjnie o charakterze osad przemysłowych. Liczba mieszkańców według stanu na dzień 30.06.2014 wynosiła 19199, a proporcjonalny podział na poszczególne jednostki administracyjne przedstawia rys. 2 .

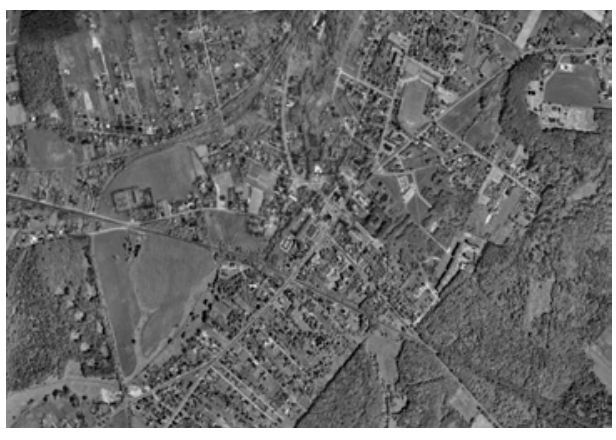

Fot. 1. Orzesze - strefa centralna Źródło: Google Earth ${ }^{\circledR}$ (dostęp: 2.08.2014)

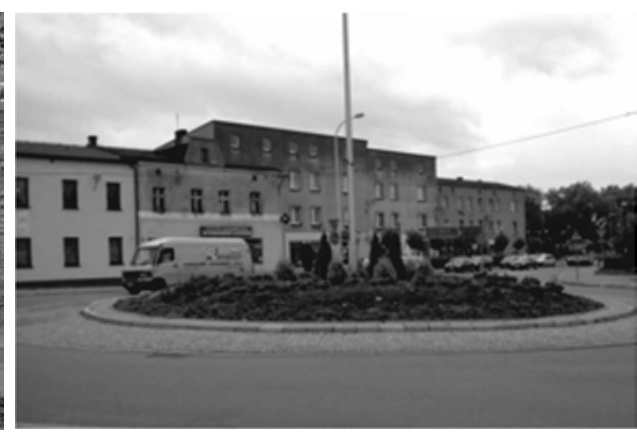

Fot. 2. Orzesze - główne rondo w centrum fot. Szymon Opania

W mieście zauważalna jest przewaga zabudowy jednorodzinnej o wiejskim rodowodzie, co powoduje odczuwalne problemy z różnorodnością funkcjonalną i intensywnością funkcjonowania przestrzeni publicznych, co jest to o tyle istotne, że przestrzeń taka jest jednym z najważniejszych elementów zagospodarowania przestrzennego (Czarnecki, Siemiński 2004). Jej jakość stanowi jednocześnie informację o aspiracjach miasta i dbałości lokalnych władz o jakość życia w mieście. Dobrze wykreowana buduje niepowtarzalny klimat miejsca, inicjuje kontakty międzyludzkie i wzmacnia poczucie więzi z miejscem. 


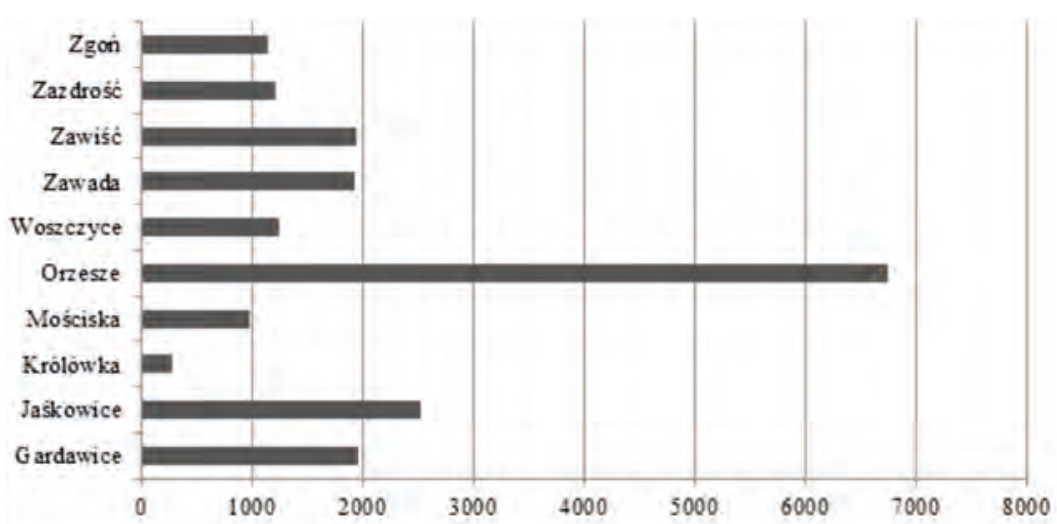

Rys. 2. Liczebność poszczególnych jednostek osadniczych miasta Orzesze

Źródło: opracowanie własne na podstawie: Lokalny Program Rewitalizacji Miasta Orzesze na lata 2010-2015 (2010)

Jednocześnie istniejące liczne tereny zieleni oraz obszary otwarte stanowią o wartości systemu ekologicznego i istniejącym wśród mieszkańców wrażeniu mieszkania w „zielonym” mieście. Do tych terenów zaliczyć należy 11 parków, w tym 8 zabytkowych, z których 4 ujęte są w ewidencji zabytkowych założeń ogrodowych w Polsce (łącznie 25,23 ha) oraz 5 cmentarzy (4 zabytkowe) z zielenią cmentarną. Tereny zielone obejmują także skwery, zieleń osiedlową, zadrzewienia wzdłuż ulic oraz pasy zieleni izolacyjnej.

\subsection{DIAGNOZA STRUKTURY PRZESTRZENNEJ}

W celu znalezienia odpowiedzi na zakres działań zmierzających do podniesienia jakości życia w mieście postanowiono wykonać diagnozę jego struktury przestrzennej, a wnioski zweryfikować pracami warsztatowymi.

Diagnoza struktury przestrzennej została wykonana w oparciu o obowiązujące dokumenty strategiczne i planistyczne miasta. Kwerenda tych dokumentów w pierwszym etapie dotyczyła sytuacji przestrzennej i obejmowała przede wszystkim części graficzne tych dokumentów, natomiast w drugim etapie diagnoza wykonana została głównie w oparciu o części tekstowe. Analizowanymi dokumentami były:

- Strategia Rozwoju Miasta Orzesze na lata 2012-2020;

- Studium uwarunkowań i kierunków zagospodarowania przestrzennego Miasta Orzesze;

- Aktualizacja Programu Ochrony Środowiska dla gminy Orzesze na lata 2012-2016 z perspektywa do roku 2020; 
- Lokalny Programu Rewitalizacji Miasta Orzesze na lata 2010-2015;

- obowiązujące miejscowe plany zagospodarowania przestrzennego.

Istotną cechą Strategii Rozwoju Miasta Orzesze na lata 2012-2020 jest sposób jej skonstruowania oparty na aktywnym uczestnictwie mieszkańców miasta. Rezultatem tych prac jest załącznik w postaci planu operacyjnego obejmującego listę zadań, wpisujących się w założenia poszczególnych domen oraz celów strategicznych i operacyjnych.

Odnoszą się one m.in. do tak istotnych elementów struktury miasta, jak przestrzeń publiczna. Jest ona jednym z najważniejszych elementów zagospodarowania przestrzennego, a dobrze wykreowana buduje niepowtarzalny klimat miejsca. „Przestrzeń publiczną tworzyć mają każde fragmenty przestrzeni miejskiej, które przeznaczone będą na realizację bezpośrednich kontaktów pomiędzy uczestnikami życia społecznego oraz innych potrzeb społecznych korzystającej z niej społeczności. Jednocześnie będą one fizycznie dostępne dla wszystkich zainteresowanych osób" (Strategia... 2012).

Liczba funkcji pełnionych przez daną przestrzeń stanowi o jej randze. Odbiór przestrzeni publicznej zależy od jakości jej zagospodarowania i otoczenia, na który wpływ mają wyremontowane elewacje, elementy małej architektury i zieleń ozdobna. Dodatkowym, bardzo istotnym elementem jej odbioru jest poczucie bezpieczeństwa.

Dla wybranych obszarów miasta, w zakresie domeny - marka Orzesze - wygodne, funkcjonalne, bezpieczne i atrakcyjne do zamieszkania miasto ze spójną i zintegrowaną miejską społecznością, został określony cel strategiczny I: budowanie tożsamości i poczucia wspólnoty w Orzeszu. Zakłada on, że Orzesze $\mathrm{w}$ perspektywie kilku, kilkunastu lat stanie się zintegrowaną gminą z funkcjonalnie zaplanowanymi przestrzeniami aktywności gospodarczej, mieszkaniowej i rekreacyjnej, a także $\mathrm{z}$ centralną przestrzenią publiczną w postaci rynku, zorganizowaną w sąsiedztwie nowych funkcji centrotwórczych (Strategia... 2012).

Analiza uwarunkowań sytuacji przestrzenno-funkcjonalnej miasta zawartych w Studium uwarunkowań i kierunków zagospodarowania przestrzennego Miasta Orzesze pozwala zidentyfikować najważniejsze problemy przestrzenne oraz ewentualne wynikające $\mathrm{z}$ nich konsekwencje i zagrożenia.

Obszar uznawany za centrum Orzesza, ze względu na gęstość zaludnienia oraz lokalizację obiektów administracji publicznej, położony jest w północnej części gminy. Obszar ten, w skład którego wchodzą: Jaśkowice, Zawada i Orzesze, tworzące tzw. śródmieście, które w 2003 roku zamieszkiwało ok. 60\% ogółu mieszkańców gminy. Znaczne odległości do pozostałych dzielnic miasta (zob. rys. 3) są przyczyną mniejszej dostępności usług zlokalizowanych w centrum administracyjnym. Każdy z ośrodków posiada swoje lokalne centrum, spełniające podstawowe funkcje. Ich rozwój jest jednak ograniczony ze względu na niewielką liczbę użytkowników. 


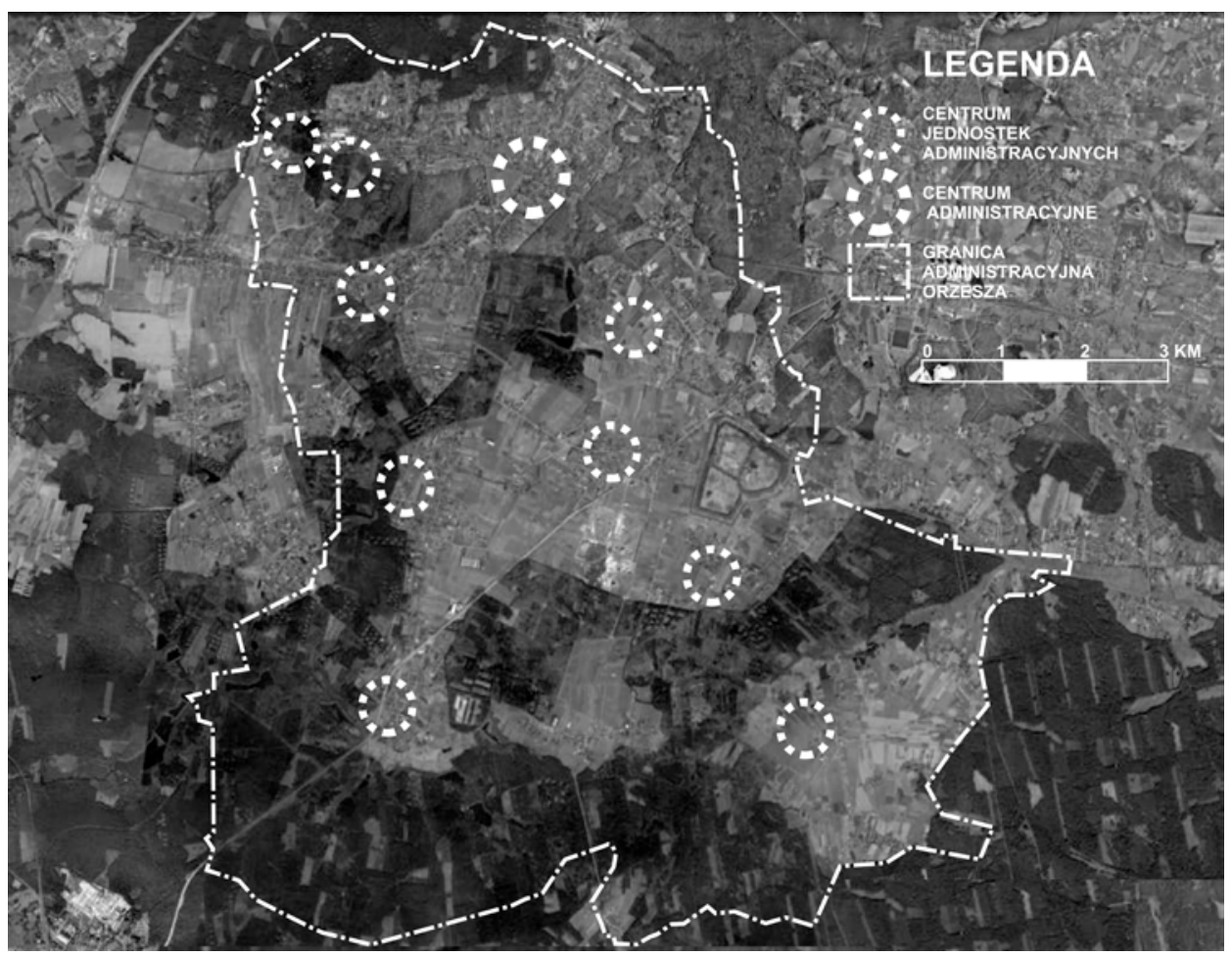

Rys. 3. Orzesze - tereny usług lokalnych w centrach dzielnicowych oraz tereny centrum administracyjnego wskazane

w Studium uwarunkowań i kierunków zagospodarowania przestrzennego

Źródło: opracowanie własne

Ponadto zauważalna jest dezintegracja przestrzeni miasta wynikająca $\mathrm{z}$ istnienia dwóch barier przestrzennych w postaci drogi wojewódzkiej DW 925 oraz linii kolejowej na kierunku Czerwiona-Leszczyny-Mikołów/Knurów. Funkcjonowanie kształtującego się centrum zaburzone zostało zatem przecięciem jego przez przeciążony układ drogowy dróg wojewódzkich DW 925 i 926, będących obecnie drogami dojazdowymi do węzła autostradowego „Rybnik” na autostradzie A1. Taki układ komunikacyjny wydziela niejako trzy obszary o dominującym, zróżnicowanym programie funkcjonalnym (rys. 4).

Dodatkowo rozwiązanie skrzyżowania tych dróg, w postaci dwóch sąsiadujących ze sobą rond, rzutuje na stan powietrza oraz ponadnormatywną emisję hałasu.

Strefa nr 1 charakteryzuje się zlokalizowanymi chaotycznie w niej obiektami handlowymi. Strefa nr 2 to fragment zieleni nadrzecznej wzdłuż Bierawki, pełniący funkcję skrótu pomiędzy kwartałami zabudowy, obiektami handlowymi 


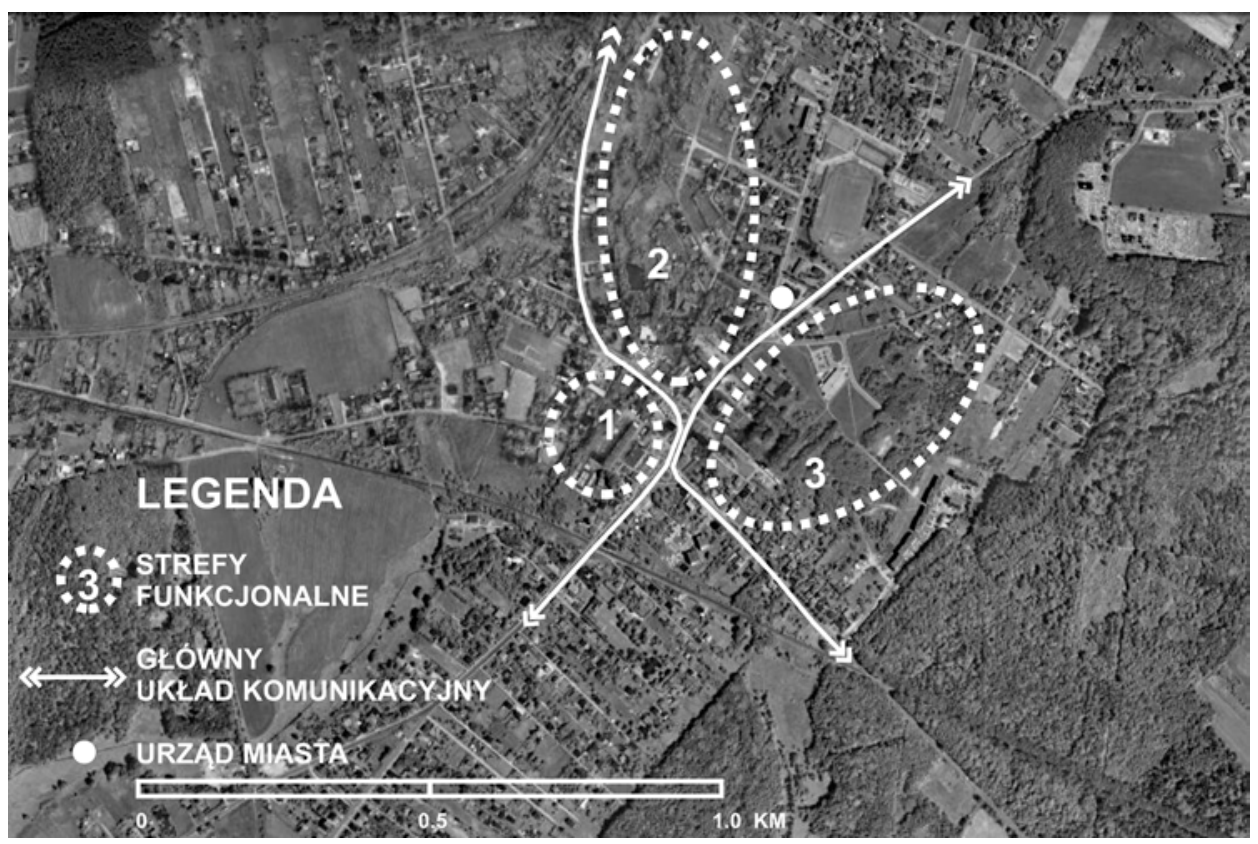

Rys. 4. Orzesze - strefa centrum administracyjnego.

Wydzielające się trzy podstrefy funkcjonalne w oparciu o układ komunikacyjny

Źródło: opracowanie własne

oraz dworcem kolejowym. Strefa nr 3 to obszar, na terenie którego zlokalizowany jest kościół pw. Nawiedzenia NMP, Miejski Ośrodek Kultury oraz tereny zieleni nieurządzonej pełniącej okazjonalnie funkcje rekreacyjne. Jest on jednocześnie naturalnym ,łącznikiem” pomiędzy osiedlem mieszkaniowym przy ul. Kwiato-wej a ścisłym centrum miasta Orzesze. W obszarze tym jednak mają miejsce zdarzenia kryminalne odnotowane przez Miejską Komendę Policji (gwałty i napady rabunkowe).

Dodatkowo strefy te zlokalizowane są w otoczeniu przeważającej zabudowy jednorodzinnej, między którą nie wykształciły się przestrzenie publiczne. Stąd wydaje się, że głównym problemem wynikającym ze struktury przestrzennej miasta jest brak jednoznacznie zdefiniowanego, jednego centrum, odpowiadającego wielkości miasta oraz odległości między dzielnicami.

Ponadto Studium pozwala i wskazuje w rozdziale 3 -Kierunki zmian $w$ strukturze przestrzennej miasta. Paragraf 8 rozdziału zaleca: wyraźne przestrzenne i funkcjonalne wyodrębnienie obszaru centrum (pkt. 5) oraz wyznaczenie miejskiego obszaru przestrzeni publicznych, w tym obszaru przestrzeni zieleni (pkt. 10) (Studium... 2010). 
Analiza zapisów Programu Ochrony Środowiska dla Gminy Orzesze na lata 2012-2016 jest istotna ze względu na przepływającą przez potencjalne centrum rzekę Bierawkę, leżącą w zlewni Odry. Płynąca w obniżeniu terenu pełni przede wszystkim rolę korytarza ekologicznego bogatego w mozaikowy układ roślinności o dużym zróżnicowaniu.

Ponadto w ramach określonego pkt. 9.1.2 Programu działania-zasoby wodne i gospodarka wodno-ściekowa, sformułowano krótkoterminowy cel strategiczny, realizowany do 2016 roku, jakim ma być ochrona, restytucja i właściwe kształtowanie pasów roślinności wzdłuż brzegów cieków wodnych (Program... 2012).

Wskazania obszarów problemowych, w ramach Lokalnego Programu Rewitalizacji Miasta Orzesze na lata 2010-2015, dokonano przede wszystkim na podstawie zagrożeń, problemów społecznych oraz występowania niezagospodarowanych terenów bądź opuszczonych obiektów. Na podstawie tak przyjętych kryteriów wyznaczono dwa obszary problemowe: Jaśkowice i Centrum. Obszar Centrum obejmuje tereny na północ od linii kolejowej Orzesze Jaśkowice-Tychy, od zachodu ograniczony Bierawką, od wschodu ul. Kwiatową, sięgający na północ do okolic budynku Urzędu Miejskiego. Część tak wyznaczonego obszaru od kościoła parafialnego po zabudowania przy ul. Kwiatowej obejmuje tereny, które były zarezerwowane pod budownictwo wielorodzinne. W związku z restrukturyzacją górnictwa poprzestano na wybudowanym osiedlu przy ul. Kwiatowej (200 mieszkań). Do tej strefy włączono również Rynek oraz niezagospodarowane tereny między Rynkiem i okolicami Urzędu Miejskiego. W obszarze Centrum wskazano do realizacji m.in. zadanie polegające na przebudowie przestrzeni miejskiej na cele gospodarcze, społeczne i kulturowe.

Działanie ma wpłynąć na sferę społeczną i ekonomiczną. Przyczynić się ma również do powstawania nowych miejsc pracy, poprawy lokalnej infrastruktury oraz pokonywania barier społecznych (Lokalny... 2010).

\subsection{WNIOSKI Z ANALIZY DOKUMENTÓW STRATEGICZNYCH I PLANISTYCZNYCH}

Analiza dokumentów strategicznych i planistycznych wykazała cechy struktury przestrzennej miasta Orzesza, które z jednej strony wymagają podjęcia działań naprawczych, natomiast z drugiej stanowią o potencjale miasta. Są to:

- brak faktycznego centrum oraz odległości między dzielnicami, które mogą być przyczyną mniejszego uczestnictwa mieszkańców z dzielnic oddalonych od centrum w życiu społecznym, gospodarczym i kulturalnym gminy. Może mieć to wpływ na skalę przestrzeni publicznych, jak i towarzyszące im aktywności społeczne;

- miasto Orzesze charakteryzuje się bardzo korzystnym położeniem w sieci transportowej regionu dzięki bliskości dwóch ważnych korytarzy komunikacyjnych, tj. autostrad A1 i A4; 
- gmina odznacza się niewielką atrakcyjnością turystyczną z jednoczesnym znacznym odsetkiem terenów zielonych, co może powodować tendencję do korzystania przez mieszkańców z własnych „wewnętrznych” zasobów terenów rekreacyjnych;

- zwiększająca się liczba mieszkańców w gminie oraz plany wzmocnienia roli centrum musi skutkować wskazaniem rezerw terenu pod zabudowę mieszkaniową;

- obszary przestrzeni zieleni zlokalizowanej w części centralnej mogą przyjmować funkcje obszaru przestrzeni publicznych, w zależności od ich szczegółowego przeznaczenia, form własności i stopnia udostępnienia dla ogółu użytkowników przestrzeni miejskiej;

- większy udział urządzonych terenów zielonych w powierzchni miasta i mniejsza uciążliwość oddziaływania przemysłu;

- uzupełnienie struktury przestrzennej miasta zabudową mieszkaniową powinno uwzględniać postulat uzyskania współczynnika intensywności zabudowy terenu nie wyższego niż 1,0 .

\subsection{WSKAZANIA DZIALAŃ URBANISTYCZNYCH}

Wnioski z analizy dokumentów strategicznych i planistycznych koncentrują się na:

- realizacji systemu komunikacji pieszej i rowerowej wykorzystując dolinę rzeki Bierawki;

- zwiększeniu intensywności zabudowy oraz realizacji zespołu zabudowy wielorodzinnej w centrum oraz zastosowaniu współczesnych form zamieszkania;

- przeznaczeniu placu za Miejskim Ośrodkiem Kultury na Otwartą Strefę Kultury.

Obszarami, które mogłyby przejąć te funkcje, uwzględniając zapisy obowiązujących miejscowych planów zagospodarowania przestrzennego „Śródmieścia” i tzw. „Centrum”, są tereny tzw. Bulwarów Bierawki oraz okolice MOK (zob. rys. 5).

Pierwszy z nich, zlokalizowany wzdłuż płynącej przez Orzesze rzeki Bieraw$\mathrm{ki}$, stanowi teren zieleni nieurządzonej. Wzdłuż rzeki istnieje naturalne połączenie ważnych punktów miasta: terenów zabudowy mieszkaniowej jednorodzinnej przy ulicach: Bukowina, Górna, M. Kopernika i Środkowa, dworca PKP i centrum z tzw. targowiskiem miejskim, omijające główne drogi o dużym natężeniu ruchu kołowego. Korzystając z takiego połączenia, mieszkańcy miasta wydeptali ścieżkę biegnącą wzdłuż Bierawki i przebiegającą przez tereny zieleni zlokalizowane przy rzece. Teren jest obecnie zarośnięty wysoką trawą, krzewami i nie jest ani zagospodarowany, ani przystosowany do komunikacji pieszej. W miejscowym planie zagospodarowania przestrzennego „Centrum”, tereny te przeznaczone są na wody śródlądowe z zielenią towarzyszącą oraz na sieci i urządzenia infrastruktury technicznej. 


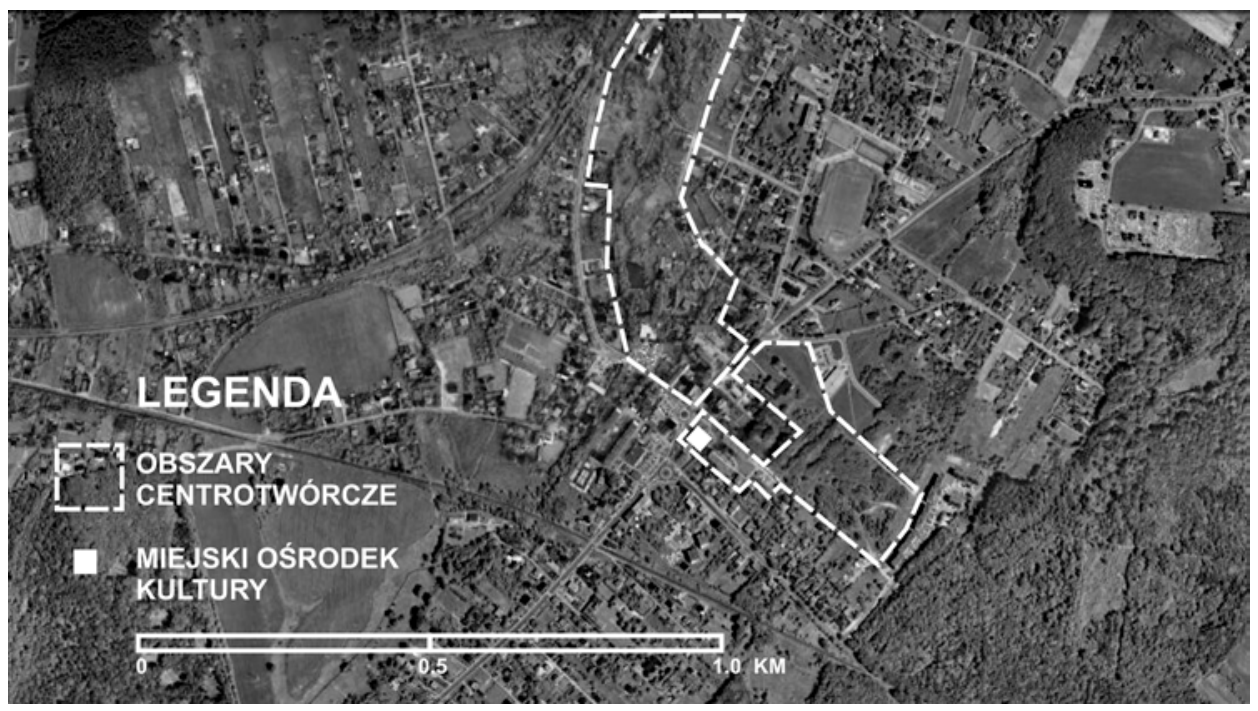

Rys. 5. Orzesze - obszary o potencjale centrotwórczym

Źródło: opracowanie własne

Teren przy Miejskim Ośrodku Kultury, zlokalizowany pomiędzy kościołem pw. Nawiedzenia NMP w Orzeszu, supermarketem Tesco i ul. Kwiatową, obecnie porośnięty jest zielenią nieurządzoną w postaci samosiejek: drzew, krzewów $\mathrm{i}$ traw. Zieleń $\mathrm{w}$ tym obszarze nie jest pielęgnowana ani utrzymywana. $\mathrm{Z}$ uwagi na swoje korzystne centralne położenie przez teren przebiegają liczne ścieżki, wydeptane i używane przez mieszkańców miasta, co dowodzi o potencjale terenu. Pozostaje on jednocześnie naturalnym „łącznikiem” pomiędzy osiedlem mieszkaniowym przy ul. Kwiatowej a ścisłym centrum miasta Orzesze. Tuż za budynkiem MOK zlokalizowany jest teren, który pełni obecnie funkcję nieurządzonego parkingu dla samochodów osobowych oraz przestrzeni niezorganizowanego ruchu pieszego.

W miejscowym planie zagospodarowania przestrzennego śródmieścia miasta Orzesze teren ten przeznacza się na cele realizacji przestrzeni towarzyszącej usługom, parku śródmiejskiego z towarzyszącymi terenowymi usługami sportu (Miejscowy... 2003).

\subsection{PRZYKŁADOWE ROZWIĄZANIA PRZESTRZENNE}

Wskazania działań były podstawą do wykonania koncepcji zagospodarowania terenu wybranych obszarów miasta, wykonanych przez studentów Wydziału Architektury Politechniki Śląskiej, pod nadzorem autora. 
Analiza dokumentów strategicznych wykazała, że istotnym i zauważalnym przez władze miasta problemem jest struktura miasta, która prowadzi do powstawania lokalnych centrów o wyraźnie ograniczonych zasięgach oddziaływania. Działania, które mogłyby naprawić taką sytuację to: połączenie istotnych funkcjonalnie punktów miasta systemem przestrzeni publicznych, zagospodarowanie terenów zieleni nieurządzonej zlokalizowanej w strefie centralnej i dążenie do zwiększenia intensywności zabudowy strefy centralnej miasta $\mathrm{z}$ równoczesnym wytworzeniem przestrzeni publicznej mogącej przejąć funkcję najważniejszego placu miejskiego - rynku.

Dla terenu zlokalizowanego wzdłuż rzeki Bierawki koncepcje przewidywały uzupełnienie struktury przestrzennej Bulwarami Bierawki, które stanowić miały kontrapunkt dla otaczających je terenów (rys. 6).

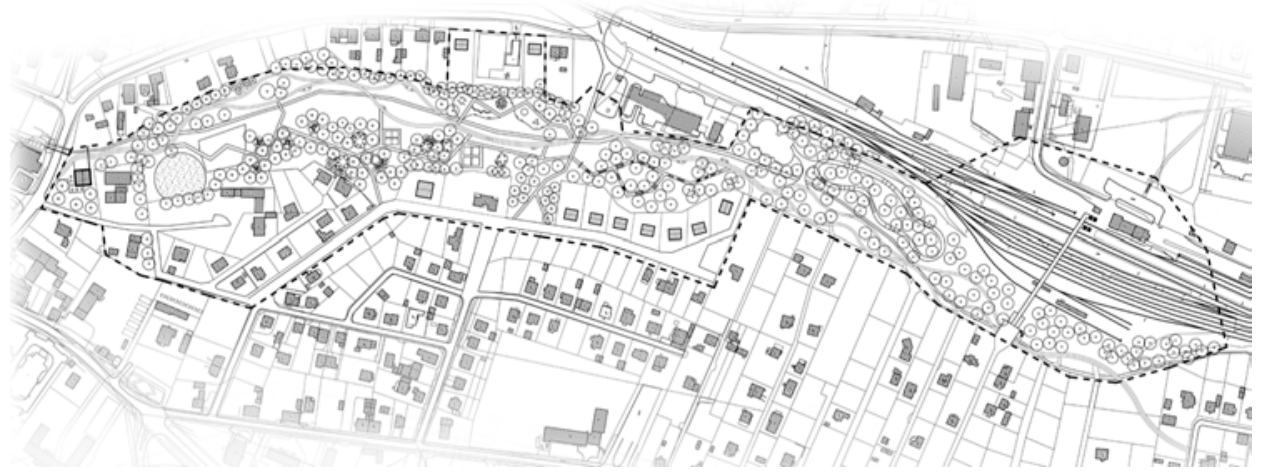

Rys. 6. Orzesze - warianty zagospodarowania tzw. Bulwarów Bierawki

Źródło: S. Opania (2015, s. 20)

Jednocześnie nowo wykreowana przestrzeń swobodnie będzie łączyć tereny dworca PKP z targiem zlokalizowanym w centrum miasta. W ten sposób dotychczas niezagospodarowane tereny staną się miejscem spotkań, dostosowanym do potrzeb wszystkich użytkowników. Obszar został podzielony funkcjonalnie na trzy strefy: obsługi dworca PKP, rekreacyjną oraz rekreacyjno-usługową. Istotnym elementem rozwiązań projektowych jest dopełnienie istniejącej tkanki zabudowy mieszkaniowej jednorodzinnej wraz z lokalizacją parkingów ułatwiających dostęp do terenów bulwarów, jak i do dworca od strony wschodniej (rys. 7).

Dla strefy nieurządzonej zieleni zlokalizowanej w sąsiedztwie ul. Kwiatowej i kościoła pw. Nawiedzenia NMP, działaniem priorytetowym było uporządkowanie struktury przestrzennej tej części miasta.

Proponowane rozwiązania uzupełniały ofertę na spędzanie czasu wolnego przez młodych mieszkańców miasta. Stąd ważnym rozwiązaniem, zgodnym z zapisami miejscowych planów zagospodarowania przestrzennego, byłoby 


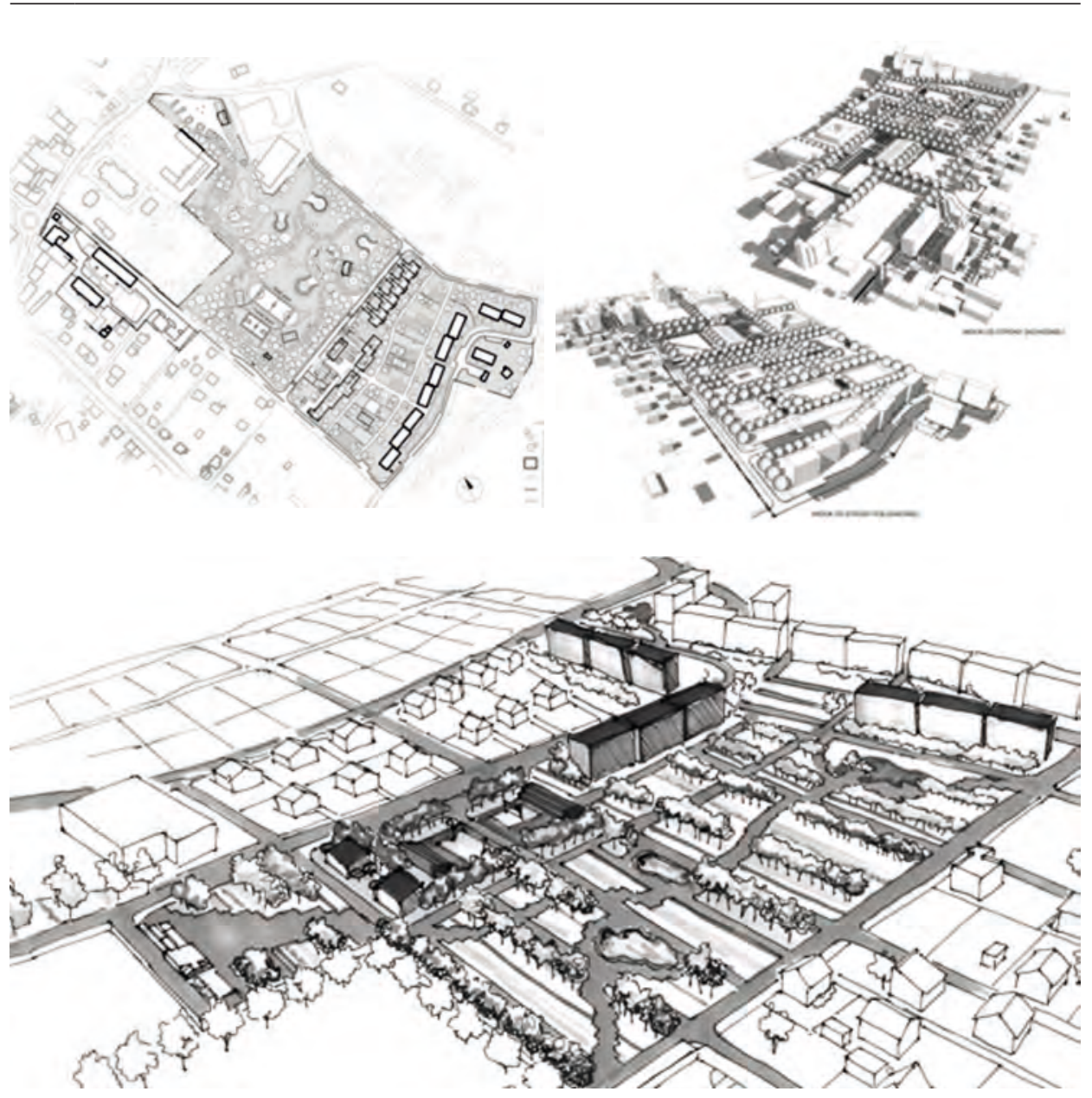

Rys. 7. Orzesze - koncepcja zagospodarowania terenu obszarów o potencjale centrotwórczym

Źródło: S. Opania $(2015$, s. 27, 29)

wykorzystanie sieci istniejących ścieżek rowerowych, wpisanie obszaru w system wraz z próbą wytworzenia formy parku miejskiego, rynku i multifukcjonalnego miejsca spotkań. Towarzyszy temu próba uzupełnienia istniejącej tkanki zabudowy mieszkaniowej jednorodzinnej i wielorodzinnej.

Bezpośrednio do tego obszaru przylega teren Miejskiego Ośrodka Kultury, w sąsiedztwie którego istnieje możliwość kreacji brakującej w mieście centralnej, miejskiej przestrzeni publicznej, dostępnej wyłącznie dla pieszych i rowerzystów - identyfikowalnej przez mieszkańców jako główny plac miejski. Miałby on pełnić funkcje reprezentacyjnej przestrzeni miejskiej, otwartej, dostępnej dla 
wszystkich, przystosowanej do prezentacji wystaw czasowych, organizacji występów, działania kina letniego związanego z działalnością Miejskiego Ośrodka Kultury, z zapleczem w MOK (rys. 8).
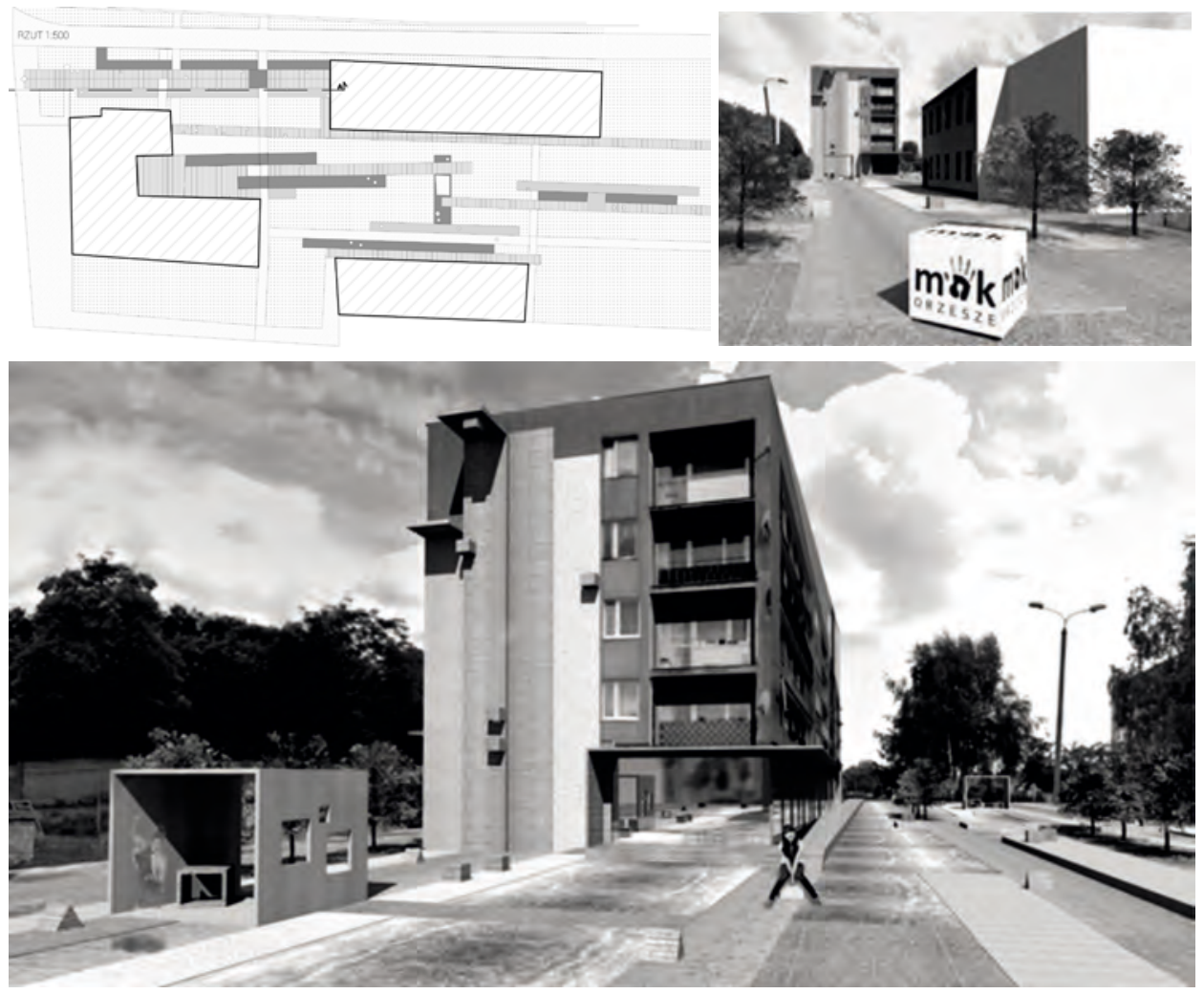

Rys. 8. Orzesze - koncepcja tzw. rynku w sąsiedztwie MOK

Źródło: S. Opania (2015, s. 33)

Efektem byłby reprezentacyjny plac kultury, kojarzony przez mieszkańców jako serce miasta. Przeznaczony na wszystkie ważne imprezy kulturalne, a ze względu na swoją lokalizację i brak ruchu kołowego chętnie byłby odwiedzany przez mieszkańców w celu spędzenia wolnego czasu.

\subsection{WNIOSKI}

Studium struktury przestrzennej małego miasta, wykonane na przykładzie Orzesza, wykazało wiele cech, które w innym świetle ukazują funkcjonowanie miasta. W tym przypadku do najważniejszych należą: rozproszenie ośrodków osadniczych, które są przyczyną mniejszego uczestnictwa mieszkańców w życiu 
społecznym, gospodarczym i kulturalnym, co ma wpływ na skalę przestrzeni publicznych, jak i towarzyszących im aktywności społecznych.

Studium struktury przestrzennej małego miasta, wykonane na przykładzie miasta Orzesze jest narzędziem, dzięki któremu można precyzyjnie określić rekomendacje projektowe dla problemowych obszarów miasta.

Wykonane na jego podstawie wariantowe propozycje projektowe pokazują różne możliwości rozwiązań funkcjonalno-przestrzennych, których realizacja mogłaby doprowadzić do poprawy jakości przestrzeni publicznych w mieście oraz funkcjonowania jego strefy centralnej.

Ich atrakcyjna wizualnie forma, zrozumiała dla wszystkich, może być podstawą do rozmowy w szerokim gronie nad możliwościami zagospodarowania wybranych obszarów miasta, a liczba wykonanych prac pozwala na wariantowe przetestowanie różnych rozwiązań funkcjonalnych i przestrzennych. Na ich podstawie można budować optymalny program funkcjonalno-przestrzenny, który można wykorzystać przy formułowaniu specyfikacji istotnych warunków zamówienia lub w otwartych konkursach urbanistyczno-architektonicznych.

\section{LITERATURA}

Bagiński E., 1988, Fenomen nowych miast wojewódzkich w sieci osiedleńczej kraju, [w:] Jałowiecki B., Kaltenberg-Kwiatkowska E. (red.), Procesy urbanizacji i przekształcania miast w Polsce, Ossolineum, Wrocław-Warszawa-Kraków-Gdańsk-Lódź.

Chmielewski J.M., 2001, Teoria urbanistyki w projektowaniu i planowaniu miast, Oficyna Wydawnicza Politechniki Warszawskiej, Warszawa.

Chojnicki Z., Czyż T., 1989, Charakterystyka matych miast regionu poznańskiego a koncepcja kontinuum miejsko-wiejskiego, [w:] Worcelli P., Gawryszewski A. (red.), Wspótczesne przemiany regionalnych systemów osadniczych w Polsce, Prace Geograficzne IGiPZ PAN, Ossolineum, Wrocław-Warszawa-Kraków-Gdańsk-Łódź.

Czarnecki B., Siemiński W., 2004, Ksztaltowanie bezpiecznej przestrzeni publicznej, Wydawnictwo Difin, Warszawa.

Duś E., 2010, Zmiany funkcji rolniczych w matych miastach województwa śląkiego, [w:] Heffner K, Polko A. (red.), Transformacja funkcji miejskich w ośrodkach lokalnych, Prace Naukowe Akademii Ekonomicznej w Katowicach, Katowice.

Gehl J., 2014, Miasta dla ludzi, Wydawnictwo RAM, Kraków.

Heffner K., 2005, Małe miasta a rozwój obszarów wiejskich, [w:] Heffner K. (red.), Problemy zagospodarowania terenów wiejskich w Polsce, Akademia Ekonomiczna, Katowice.

Heffner K., 2008, Zmiany roli i kierunków rozwoju matych miast w strefach metropolitalnych, [w:] Heffner K., Marszał T. (red.), Ośrodki lokalne w strefie oddzialywania wielkich miast, „Biuletyn KPZK PAN”, 238, Warszawa. 
Heffner K., Czarnecki A., 2005, Małe i średnie miasta w lokalnych i regionalnych strategiach rozwoju, [w:] Heffner K., Marszał T. (red.), Problemy rozwoju matych miast $w$ wymiarze lokalnym i regionalnym, „Biuletyn KPZK PAN”, 220, Warszawa.

Heffner K., Marszał T., 2012, Przestrzeń publiczna małych miast, „Studia KPZK PAN”, 144, Warszawa.

Jerczyński M., 1977, Funkcje i typy funkcjonalne polskich miast, [w:] Statystyczna charakterystyka miast - funkcje dominujace, „Statystyka Polski”, 85, Warszawa.

Lokalny Program Rewitalizacji Miasta Orzesze na lata 2010-2015, 2010, Orzesze.

Mazur-Belzyt K., 2009, Współczesny wizerunek małego miasta, [w:] Sulimowska-Ociepka A., Ujma-Wąsowicz K., Zalewski K., Rendchen Sz. (red.), ULAR 4, Odnowa krajobrazu miejskiego. Uroda miasta, Wydział Architektury Politechniki Śląskiej, Gliwice.

Mazur-Belzyt K., 2015, Efekty rewitalizacji przestrzeni centralnych małych miast. Rynek - scena miejskiego życia bez aktorów, Markowski, T. (red.), Powrót do centrum miasta - wyzwanie dla krajowej polityki miejskiej, „Studia KPZK PAN”, Warszawa.

Miejscowy plan zagospodarowania przestrzennego Śródmieścia miasta Orzesze, Uchwała Nr VIII/55/03 Rady Miejskiej w Orzeszu z dnia 30 maja 2003 roku, 2003, Orzesze.

Miejscowy plan zagospodarowania przestrzennego obejmujący teren położony w Orzeszu $w$ rejonie ograniczonym ul. Gliwicka, granica Gminy Ornontowice, pótnocna linia lasu, ul. Św. Wawrzyńca, wschodnia linia lasu, ul. Wiosny Ludów oraz ul. Matejki, Uchwała Nr XIV/79/07 Rady Miejskiej w Orzeszu z dnia 7 listopada 2007 roku, 2007, Orzesze.

Opania S., 2015, Studium urbanistyczne zagospodarowania wybranych obszarów miasta Orzesza wraz z rekomendacjami projektowymi, Gliwice-Orzesze.

Parysek J., 2004, Trajektorie rozwoju miast polskich w latach 1992-2002, [w:] Parysek J. (red.), Rozwój regionalny i lokalny w Polsce w latach 1989-2002, Instytut Geografii Społeczno-Ekonomicznej i Gospodarki Przestrzennej Uniwersytetu im. Adama Mickiewicza w Poznaniu, Poznań.

Polko A., 2010, Funkcja mieszkaniowa małych miast w strefie oddziaływania Aglomeracji Górnośląskiej, [w:] Heffner K., Polko A. (red.), Transformacja funkcji miejskich w ośrodkach lokalnych, Wydawnictwo Akademii Ekonomicznej w Katowicach, Katowice.

Program Ochrony Środowiska dla Gminy Orzesze na lata 2012-2016 z perspektywa do roku 2020, 2012, Orzesze.

Strategia Rozwoju Miasta Orzesze na lata 2012-2020, 2012, Centrum Doradztwa Strate-gicznego, Kraków-Orzesze.

Strategia Rozwoju Województwa Śląskiego ,, ŚLACSIE 2020+”, 2013, Sejmik Wojewódz-twa Śląskiego, Katowice.

Studium uwarunkowań i kierunków zagospodarowania przestrzennego Miasta Orzesze, 2010, Orzesze.

Szlachta J., 1980, Zmiany ludnościowe i terytorialne $w$ matych miastach polskich $w$ latach 1960-1978, „Miasto”, 7, Warszawa. 


\begin{abstract}
The concept of small town contains meanings that seem to be important from the point of view of spatial structure analysis. 'Small' refers to the number of inhabitants, which is the basis for including a city in a certain size group. 'Town' or 'city' in the basic sense can be considered as a historically shaped settlement unit. The components of the city: buildings, public spaces, technical infrastructure, urban composition and an active community make up urban space and the life in it - the essence of urbanity.

Silesian voivodeship contains 35 urban settlements which can be categorized as small towns. The smallest of them is Sośniowice with about 2000 inhabitants, and the largest is Orzesze with a population of 19199.

So the question is whether the size of a city affects the quality of life in the city? And are the conditions in the largest of them - Orzesze - better than in other, smaller towns?

The aim of the article is thus an attempt to demonstrate the usefulness of the study of cities' spatial structure as a tool in the field of spatial planning and urban design, allowing to answer the stated question and identify possible corrective actions aimed at improving the quality of life in the city.
\end{abstract}

\title{
Keywords
}

Spatial structure, analysis of the problems, spatial planning. 